\title{
Theoretical Thinking and Practical Research on the Establishment of Teaching Base for Sino-Russian Folk Artworks
}

\author{
A Case Study of Heihe University
}

\author{
Yuyun Wang \\ Heihe University \\ Heihe, China
}

\begin{abstract}
According to the spirit of the document of Construction Planning of Strong Higher Education Province of Heilongjiang by China and the Education Department, and the "Longjiang Silk Road Economic Belt" construction spirit to implement "the Belt and Road Initiative" strategic planning, this paper explores the theoretical thinking and implementation demonstration to create a research and development and creation base for Sino-Russian folk artworks, taking Heihe University as an example and in combination with the strategy of national cultural power and the needs of regional economic development in Heilongjiang Province and Northeast China.
\end{abstract}

Keywords-Sino-Russian folk artwork; teaching base; practice research

\section{INTRODUCTION}

With the support of provincial department of education and under guidance of the scientific orientation of running a school with its own characteristics, Heihe University always insists on promoting the development of the college with the project construction in terms of construction of schooling connotation. Heihe University currently has national specialty, provincial key specialty, and national off-campus practice base for college students, Heilongjiang art experiment teaching demonstration center, innovation and entrepreneurship training mode reform of art design, Russian oil painting research base supported by central government developed in colleges and universities, and other quality engineering construction projects. Through the construction of various projects, Heihe University exerts its geographical advantages of being located at the border port between China and Russia in the comparison and integration of Chinese and Russian art, absorbs and draws lessons from Russia's advanced schooling philosophy, excavates Russia's abundant art teaching resources and highquality teacher resources, and possesses perfect infrastructure and environment, which has greatly advanced the reform and innovation of scientific research achievements, promoted the internationalization of teaching teams, and made major breakthroughs in the cooperation and exchange with Russia in particular, providing a broad space and practical basis for this project in academic research, cooperation and exchanges, and reform and innovation.

\section{THEORETICAL THINKING ON THE ESTABLISHMENT OF TEACHING BASE FOR SINO-RUSSIAN FOLK ARTWORKS}

\section{A. The Foundation for the Establishment of a Teaching Base} for Sino-Russian Folk Artworks

1) Existing research team: Heihe University has actively introduced Russian experienced professional research experts including meritorious painters, artists and folk artists in past project construction and cooperative education, and gradually formed a high-quality research team cluster with advanced talents. The project is to be composed of excellent teachers from universities in China and Russia. It shares teacher resources, and has a Sino-Russian folk art research team with high research level, strong scientific research strength and distinct characteristics in the teaching and practice of SinoRussian art education, providing an important human resources guarantee for the smooth development of the project.

2) Sino-Russian communications and cooperation: As a bridgehead and hub of cultural and artistic exchanges with Russia, Heihe University has built a platform for domestic universities to exchange and cooperate with Russia in art, and highlighted its unique functions and advantages as a border university.

At present, Heihe University has carried out art cooperation and exchanges with more than ten Russian universities, such as the Moscow State Academic Art Institute named after V.I. Surikov, National Blagoveshchensk Normal University, Amur State University, and so on, demonstrating its school-running characteristics. Heihe University has hosted the Russian Oil Painting Master Class of the Ministry of Education for 4 times. It regularly holds short-term creative guidance classes and art forums; organizes works exhibition for excellent graduates every year, displays the works of teachers and students in the Sino-Russian culture collection of the Ministry of Culture, and holds a joint creation exhibition of Sino-Russian teachers and students; organizes teachers and students from other universities and colleges to go to Russia for sketching; establishes a research base for young Chinese painters from Moscow State Academic Art Institute named 
after V.I. Surikov; holds a summer camp for Chinese and Russian college students and a seminar for young painters every year, which lay a good foundation for Sino-Russian cooperation and exchanges for the implementation of the project.

3) Significance of creating the teaching base: The construction project of research and development and creation base of Sino-Russian folk artworks aims to gathering education resources of Sino-Russian folk artworks, triggering innovation between Sino-Russian universities and the folk art industry, and transforming the folk art resources of SinoRussian boundary river into cultural artworks. It makes efforts to build high-level large-scale bases for the creation, influence and dissemination of artworks that meets the strategic needs of the regional economic and cultural power of China and Russia, such as research and development and creation centers of Sino-Russian folk artworks, Sino-Russian folk artwork experience centers, Sino-Russian folk artwork exhibition centers, centers for training and gathering applied talents of Chinese and Russian folk arts and crafts.

\section{B. Analysis of Necessity}

1) Building a "research and development and creation bases of Sino-Russian folk artworks" is the need to implement the strategic planning of the Longjiang Silk Road Economic Belt in our province: The introduction of "the Belt and Road Initiative" strategy and the "Longjiang Silk Road Economic Belt" planning in our province have clearly pointed out the direction and set the goal for further expanding the educational, scientific, technological and cultural exchanges and economic and trade cooperation with Russia. As a SinoRussian border port city, Heihe City has laid a foundation for expanding exchanges and cooperation in the field of science, technology, culture and education relying on advantageous geographical position and friendly exchanges for many years. The construction of "research and development and creation bases of Sino-Russian folk artworks" can give play to the geographical location advantages of Heihe City and the professional advantages of discipline of Heihe University, and effectively serve "the Belt and Road Initiative" strategy and the "Longjiang Silk Road Economic Belt" construction.

2) Building a "research and development and creation bases of Sino-Russian folk artworks" is the need to achieve the resource sharing and joint development of twin cities: As two neighboring cities, Heihe and Blagoveshchensk, the twin cities of China and Russia has conducted extensive exchanges in various fields over the years, and their frequent personnel movements and friendships are increasing. The "two countries and one city" concept proposed by the government of Heihe city is a new mode of realizing resource sharing and common development in the Sino-Russian border areas. The SinoRussian twin cities have become a large channel, window, large and platform for the people of the two countries. The city of Blagoveshchensk is the education center of Amur region and has 4 colleges and universities, 12 secondary specialized schools, and has the reputation of "student city". It has developed education and profound cultural heritage, and introduces the high-quality cultural education resources to promote the development of related fields in Heihe City for many years. The construction of "research and development and creation bases of Sino-Russian folk artworks" is conducive to achieving the Scientific, technological and cultural resources sharing of two rivers and one bank.

3) Building a "research and development and creation bases of Sino-Russian folk artworks" is the need for Hehei to fully create a cultural port city: The Heihe Overall Urban Planning from 2000 to 2020 has determined the development orientation of Heihe city: "to build Heihe City into a distinctive international trade and international tourism city and a modern port city characterized by waterfront ecological garden by integrating the regional culture and national culture of Northern China and Chinese-Western culture." This positioning fully considers the reality of economic and social development in Heihe City, and the construction of "research and development and creation bases of Sino-Russian folk artworks" will promote to achieve this goal.

4) Building a "research and development and creation bases of Sino-Russian folk artworks" is the need for tower of ivory to serve local socio-economic development: As the only university in Heihe City, Heihe University shoulders the heavy responsibility of serving local economic and social development. The construction of "research and development and creation bases of Sino-Russian folk artworks" can give full play to the functions of colleges and universities in personnel training, scientific research, society serving, and cultural heritage innovation, promote the prosperity of Heihe City's cultural and educational business, build Heihe City into a big platform and channel for cultural and educational exchanges with Russiain Heilongjiang province and even three provinces in the northeast of China, which in turn has led to the rapid development of the tourism and trade industry and made Heihe city, bright pearl in the North of China, present a more special charm.

\section{Feasibility Analysis}

The construction of research and development and creation bases of Sino-Russian folk artworks will help to make good use of the high-quality educational resources of Russian folk art, make innovation in the development and utilization of Sino-Russian folk art products, improve exchanges in folk art between China and Russia, and boost the cooperation in folk art and culture industries between China and Russia. Besides, it will also be beneficial to establish a new platform integrating education teaching, cultural communication and product exhibition and sales of Chinese and Russian folk art, arouse students' interests in learning, improve teachers' and students' creative ability, and advance the inheritance and innovation of Chinese and Russian intangible cultural heritage.

1) Location advantages create opportunities for the construction of "research and development and creation bases of Sino-Russian folk artworks": The geographical 
advantages of Heihe City across the river from Russia, the establishment of trade zones and simplified entry procedures and other convenient conditions are conducive to promoting exchanges and cooperation with Russia in various fields. Both Heihe City and Heihe University have formed unique cultural heritage and human resources in the border areas in such exchanges, which have become the prerequisites for the construction of "research and development and creation bases of Sino-Russian folk artworks".

2) Years of exchanges have laid a foundation for the construction of "research and development and creation bases of Sino-Russian folk artworks": During many years of exchange and cooperation with Russia in education and culture, Heihe University has continuously broadened its thinking, summarized experience and explored effective ways of communication. In the process of exchanges, Heihe University has forged profound friendship with many Russian universities, scientific research institutes and literary and art organizations, and established a good prestige. In particular, Russian teachers and students attend the annual opening ceremony, sports meeting (attended by more than ten universities in the far east region of Russia), science, technology, culture and art festival, youth exchange activities and other large-scale activities of Heihe University. The exchange of folk art and oil paintings frequently becomes a highlight of the cultural and educational exchange for Heihe University and Russia. These are the solid foundation for the construction of "research and development and creation bases of Sino-Russian folk artworks".

3) The characteristic platform provides a bridge for the construction of "research and development and creation bases of Sino-Russian folk artworks": The Russian center, exchange base for Chinese and Russian university students, training base for students studying in Russia, Confucius Institute, training base for economic and trade talents with Russia in Heilongjiang Province, Heilongjiang research institution for TRIZ theoretical, base for academic exchange of Sino-Russian history and culture in Heilongjiang, research base for the education in far east region of Russia, and other national and provincial special platforms, which are settled in Heihe University, play the role of "hub station" in the exchange of science, technology, culture and education with Russia. These measures help Russia introduce and use highquality educational resources, advanced science and technology and talents, promotes all-round exchanges in culture, art and sports between China and Russia, and contributes to the promotion of Chinese language and the external dissemination of Chinese culture. On the basis of these platforms, the "research and development and creation bases of Sino-Russian folk artworks" is built into a SinoRussian high-level and all-round cooperation platform for art and culture industry, which has incomparable advantages over other universities.

\section{PRACTICAL RESEARCH ON THE ESTABLISHMENT OF} TEACHING BASE FOR SINO-RUSSIAN FOLK ARTWORKS

\section{A. The Purpose of Realization of the Teaching Base}

1) Building a Sino-Russian cultural industry cooperation and development base: Focusing on the needs of development strategies of "the Belt and Road Initiative" and "Longjiang Silk Road Economic Belt", we should build a high-standard and high-quality Sino-Russian cultural industry base for teaching practice, scientific research and artistic exchange that is in line with the development of Heilongjiang cultural industry, highlights the interaction and exchanges between Chinese and Russian universities and art groups, and is equipped with advanced instruments and equipment, shared resources and open service.

2) Developing and designing folk art products with the cultural connotation of Sino-Russian boundary river: We should take advantage of our geographical advantages to absorb the unique cultural and artistic resources of China and Russia. Facing with Chinese traditional culture, Russian exotic culture and local regional cultural resources, we should focus on the output of cultural and artistic products with the characteristics of distinctive painting works, regional product design, diversified artistic products, and distinctive SinoRussian boundary river, innovate the connotation of cooperation and exchange with Russia in cultural industry, attach great importance to cultivating applied talents' ability to practice and innovate, comprehensively advance the cultivation of high-quality applied talents to serve regional cultural development, and promote the transformation of cultural and artistic resources of Sino-Russian boundary river into cultural products.

3) Building a practical platform for the folk art industry shared by Chinese and Russian universities: We should further disseminate the culture and art of China and Russia, realize cultural exchanges and collisions between China and Russia, build a platform for scientific research, practice and exchange of Chinese and Russian art in colleges and universities throughout the country, promote the construction and development of Russian art education, teaching reform and innovation project of colleges and universities in Heilongjiang province and even the whole country, and form a practice and innovation base of Sino-Russian folk art industry with distinctive advantages for domestic universities.

\section{B. Research Content of the Teaching Base}

The construction project of research and development and creation base of Sino-Russian folk artworks makes efforts to build a high-level large-scale base for the creation, influence and dissemination of artworks that meets the strategic needs of the regional economic and cultural power of China and Russia, such as research and development and creation centers of Sino-Russian folk artworks, Sino-Russian folk artwork experience centers, Sino-Russian folk artwork exhibition centers, centers for training and gathering applied talents of Chinese and Russian folk arts and crafts. 
First, the project will focus on the strategic goal of making China a cultural power, and strive to transform the SinoRussian folk artworks into a real cultural industry through the research and development and creation of various centers in the construction of the "Longjiang Silk Road Economic Belt". Based on the cultural and artistic background of the boundary river between China and Russia, we will concentrate on studies relying on the construction of projects, focus on the cultivation of "dual creative" talents, take great pains to advance the coordination and integration of folk art teaching, design practice and industrial projects, make use of geographical advantages to absorb distinctive resources of Sino-Russian folk culture and art, develop folk art products with local, national and international characteristics, innovate the connotation of cooperation and exchange with Russian cultural industry, give impetus to the transformation of cultural and artistic resources of Sino-Russian boundary river into cultural products, and then establish the research and development and creation bases of Sino-Russian folk artworks.

Second, we will establish a Sino-Russian folk artwork experience center, and foster a platform for cross-border exchange of folk art between China and Russia to expand the scale and influence of the subject of Sino-Russian folk art. Besides, we will create a platform for folk culture industry, actively build a brand of "dual creative" artistic talents training that serves Sino-Russian cooperation and the frontier, innovate the teaching system of practical courses, promote the establishment of theory and practice, and domestic and foreign curriculum models, and strengthen special practical courses to create special Sino-Russian practice course with strong operation and good teaching effect. We will take the cultural and artistic resources of Sino-Russian boundary river as the background to transform them into cultural products, advance the continuous improvement of students' practical and innovative abilities, and promote the regional characteristics and core competitiveness of talent training.

Third, we will establish a center for training and gathering applied talents of Chinese and Russian folk arts and crafts, highlight the soft power of Sino-Russian folk art education resources clusters, build a demonstration area for Sino-Russian folk culture and art exchanges, create an atmosphere of innovation between Chinese and Russian universities and the folk art industry, boost the output of more excellent and highend cultural and artistic products, and contribute to the overall development of regional economy and cultural undertakings.

Fourth, the project will establish a Sino-Russian folk artwork exhibition center and a Sino-Russian folk culture art exhibition platform to form a sales platform combining art and commerce. The project will expands the scope of cooperation with Russian universities and domestic universities, increase the number of cooperation universities between China and Russia, and strive to develop and establish cooperative relations with the central region of Russia on the basis of cooperation with the Far East region of Russia. Through regular sales exhibition of innovative cultural and artistic products between China and Russia, training of Sino-Russian young teachers, and joint activities of collecting folk songs and sketching of Chinese and Russian artists, we will establish a new platform with high influence for domestic and foreign art cooperation and exchange that integrates the form of practical teaching, artistic creation, academic exchange and joint product research and development, to promote the exchanges and cooperation between Heilongiiang and the Russian Far East in the fields of education, culture and art. Moreover, we will promote the development of Sino-Russian tourism economy, and consolidate the cultural foundation of generations of friendship between China and Russia, to lay a good folk foundation for the inheritance and protection of intangible culture, Sino-Russian economic and trade cooperation and Sino-Russian humanistic cooperation.

\section{CONCLUSION}

During the establishment of teaching base for Sino-Russian folk artworks, we will focus on the strategic goal of making China a cultural power, and strive to transform the SinoRussian folk artworks into a real cultural industry through the research and development and creation of various centers in the construction of the "Longjiang Silk Road Economic Belt". We will foster a cross-border exchange platform for SinoRussian folk art to expand the scale and influence of the subject of Sino-Russian folk art. Besides, we will create a platform for folk culture industry, and build a brand of "dual creative" artistic talents training that serves Sino-Russian cooperation and the frontier.

\section{REFERENCES}

[1] Zhu Zhengwei, Yuan Qiaoying, Liu Dongyan. Exploration and Practice of Strengthening the Construction of Practical Teaching Base [J]. China University Teaching, 2009, (8): 66-67. (in Chinese)

[2] Jiang Jie. Exploration on the Construction of Practical Teaching Base in Higher Vocational Colleges [J]. Occupational Circle, 2007, (3): 109-110. (in Chinese)

[3] Han Xichang, Zhang Yuyan. Exploration and Practice of Jointly Establishing Internal Practice Teaching Base by University and Enterprise [J]. Journal of Shenyang Institute of Engineering (Social Science Edition), 2010, 6 (2): 243-245. (in Chinese) 